\title{
The "Double-edged Sword" of Institutional Power: COSATU, Neo-liberalisation and the Right to Strike ${ }^{1}$
}

\author{
Carin Runciman, University of Johannesburg, South Africa
}

\begin{abstract}
On 1 January 2019 amendments to the Labour Relations Act came into force that significantly altered and curtailed the right to protected strike action in South Africa. Internationally, the right to strike has been eroded in recent years with many countries adopting legal provisions that violate the International Labour Organization's principles. Comparatively, the rights of South African workers to go on protected strikes remain better than many other places in the world, a reflection of the militant history of the South African labour movement. But the erosion of these rights, with the active support of the Congress of South African Trade Unions, should be a cause for concern for activists and labour scholars in South Africa and beyond. This article develops the Power Resources Approach to consider how union institutional power has entrenched neo-liberalism in South Africa. Grounding the analysis of institutional power within the analytical framework of corporatism allows this article to develop an analysis of institutional power that is attentive to class forces. This provides an avenue for understanding the "double-edged sword" of institutional power in the South African context in order to comprehend when and under what circumstances trade unions advance and defend the interests of the working class and when they defend those of capital.
\end{abstract}

\section{KEY WORDS}

labour; neo-liberalism; institutional power; corporatism; South Africa

\begin{abstract}
The most historic and progressive changes to South Africa's labour legislation were adopted overwhelmingly by the National Assembly on Tuesday [29 May 2018]. They were the most significant and progressive amendments to our labour laws since the end of apartheid and the dawn of our new democracy in 1994 (Matthew Parks, Parliamentary Coordinator, Congress of South African Trade Unions, 2018).

We believe that the Bills upset the delicate balance that was struck between workers and employers' rights in the Constitution. They represent the most glaring attack on workers since the dawn of democracy and are no different to those introduced in Britain by the late Prime Minister Margaret Thatcher and Ronald Reagan in the United States. Their project, just like these Bills, was designed to disarm and emasculate workers (South African Federation of Trade Unions, 2018).
\end{abstract}

The quotations above represent two very different perspectives on the likely impacts of

\footnotetext{
${ }^{1}$ I would like to thank the anonymous peer reviewers and editors for their detailed and considered comments on earlier drafts of this article, which helped to clarify the argument. I'd also like to thank all of my comrades at the Simunye Workers Forum who have shaped and refined my understanding of the key challenges confronting the labour movement in South Africa today. Particular thanks must go to Ighsaan Schroeder for the many conversations that helped to develop the analysis within this article.
} 
amendments to the Labour Relations Act (LRA) that were signed into law on 1 January 2019. The Congress of South African Trade Unions (COSATU), the largest trade union federation and Alliance partner to the African National Congress (ANC), played a significant role in negotiating the amendments. In contrast, the South African Federation of Trade Unions (SAFTU), a breakaway from COSATU, joined other civil society organisations in opposing the Bills that led to the legislative amendments, including leading a nationwide strike on 25 April 2018. The differences between how the two federations responded to the Bills represent more than just the political fallout between SAFTU and COSATU; they illuminate the use of trade union institutional power.

The Power Resources Approach (PRA) has become one of the dominant conceptual tools in contemporary labour studies and has generated significant debates within the Global Labour Journal. The focus of this article is to analyse trade union institutional power. Following the critiques made by Gallas (2016, 2018), this article argues that the analysis of power resources is often abstracted from a wider understanding of class relations and this is particularly the case with the analysis of institutional power. Institutional power, this article argues, cannot only be understood as deriving from structural and associational power. It must also be understood as a reflection of class forces. Furthermore, while scholars often raise the "double-edged" nature of institutional power, few scholars advance an analysis that reflects the ends to which this power is put (Nowak, 2018). This article intends to address this gap through an analysis of how COSATU has used its institutional power to support changes to labour law that have, I argue, entrenched neo-liberalism.

The article locates the analysis of institutional power within the framework of corporatism in order to ground the discussion within an understanding of class forces. Developing this analysis, the article then goes on to examine the 1995 LRA as an example of the failure of the corporatist framework to deliver "radical reform" in the interests of the working class (Von Holdt 1992). Indeed, rather than providing radical reform the 1995 LRA, I argue, set a trajectory that weakened trade unions. As Humphrys and Cahill (2017) argue, it is important to not simply understand trade unions as "victim[s] of neoliberalising processes", but also as an active agent making deliberate choices and, at times, compromises with neo-liberalism that have undermined the strength of organised labour. This article considers that the "crisis of representation" faced by COSATU is not simply a product of the reorganisation of work but also one emanating from its own strategic and political choices. The crisis facing organised labour provides the context for the recent amendments to the LRA. As the article will demonstrate, COSATU alongside the Federation of Unions of South Africa (FEDUSA) and the National Council of Trade Unions (NACTU) made significant compromises on the right to strike in order to win concessions from the state and capital that will safeguard their own institutional power. The consequences for the labour movement and the working class as a whole are likely to be profound.

\section{The Double-edged Sword of Institutional Power}

Recent debates on the PRA have been a key part of the scholarship produced within the Global Labour Journal. It is not my intention to reproduce all of the debates here but to focus specifically on the intended uses of the PRA and the analysis of institutional power. The PRA has been explicitly framed around the "revitalisation of trade unions" and has deservedly won praise as a tool which labour scholars and activists alike can use to analyse and inform concrete struggles (Gallas, 2018). However, as Nowak (2018: 353) contends, the PRA approach has often lacked a critical engagement about the "the ends to which those resources could be used". This is perhaps particularly the case with the analysis of institutional power.

While those who support and defend the PRA recognise that institutional power is a 
“doubled-edged sword” (Schmalz, Ludwig and Webster, 2018: 121), there is not enough critical scholarship as to what this might mean. Furthermore, as Gallas (2016: 270) highlights, institutional power has sometimes unhelpfully been equated with workers' power but "the activities of unions are only instances of the exercise of working-class power if they defend, consolidate or improve the position of the working class". It is therefore necessary, as Gallas raises, to consider when and under what circumstances trade unions advance and defend the interests of the working class and when they advance the interests of capital.

This has important consequences for the stated aim of the PRA, which is to revitalise trade unions. Schmalz, Ludwig and Webster (2019) dismiss the critiques of Gallas and Nowak as belonging to the pessimistic tradition of trade union analysis that ultimately regards unions as inhibiting revolutionary transformation. However, what Gallas (2018) and Nowak (2018) draw attention to is the need for sober analysis of how trade unions have wielded their institutional power and to what ends. If, as Humphreys (2018) argues in relation to Australia, trade unions have been significant agents in advancing neo-liberalism then we must, at least, pause to reflect on what we, as labour scholars and activists, are trying to revitalise.

I propose to locate an analysis of COSATU's institutional power within a consideration of the function of corporatist relations. The value of this framework is that it provides a way to view how relations between the state, capital and labour are structured, something which Schmalz and his colleagues highlight as one of the limitations of the PRA (Schmalz et al., 2019: 88). Viewing institutional power within a corporatist framework thus provides a more comprehensive analysis of the double-edged nature of institutional power and the consequences that have played out for the working class in South Africa.

\section{Corporatism and Neo-corporatism}

The concepts of corporatism and neo-corporatism originated to analyse the state-capital-labour relations that emerged in post-war Western Europe. In this current period of neo-liberal capital, it would be appropriate to question whether they continue to have relevance today. Furthermore, it would also be apposite to consider what utility they may have in the South African context. In this section, I will provide an overview of how the concepts of corporatism and neo-corporatism have been defined and suggest why they provide an appropriate conceptual framework for analysis.

In the first wave of corporatist literature, the predominant focus was on the institutionalised structures of interest representation between the state, capital and labour (Bramble and Ollett, 2007). From the 1970s onwards scholars began to pay more attention to processes of social concertation as a form of policy-making, which they referred to as neo-corporatism (Molina and Rhodes, 2002). As Baccaro (2003) highlights, the boundaries between these concepts were frequently blurred and neo-corporatism was often used to refer to both the institutionalised structures of interest and processes of social concertation, with an underlying assumption that the appropriate institutionalised structures would promote social concertation.

An underlying weakness of a significant portion of this literature has been, as Panitch (1981) argues, that it failed to consider power relations, especially relations of class power, between the state, capital and labour. This neglect of the analysis of power means that, as Bramble and Ollert (2007: 571) argue, the ultimate function of corporatism - "to shift material resources and power from the working class to the capitalist class" - has been obscured. If the concept of corporatism is rooted in an understanding of class relations, as Bramble, Ollert and Panitch have all observed, then the distinct features of corporatism, such as social pacts and forms of concertation, are

Global Labour Journal, 2019, 10(2), Page 144 
understood as processes through which working-class power is contained and rolled back in favour of the capitalist class.

\section{Corporatism and the Failure of "Radical Reform" in the 1995 LRA}

At the end of the 1980s in South Africa, the working class had "almost revolutionary potential" (Bramble and Ollert, 2007: 586). The independent trade unions that had started in the early 1970s evolved into what became COSATU and played a leading role in working-class militancy that would eventually bring the National Party to the negotiating table with the ANC.

COSATU first entered into formal discussions with the then exiled ANC about their relationship in 1986; after a series of meetings the federation committed itself to a liberation movement "headed by the ANC" (cited in Von Holdt, 1987: 101). Although there were still calls for COSATU to form its own independent political organisation, these debates began to close from 1987 onwards, paving the way for the formal establishment of the Tripartite Alliance after 1990 (Beresford, 2016: 11). In the South African context, as Fine (2016) observes, the analysis of corporatism cannot be abstracted from an analysis of relations within the Tripartite Alliance between the ANC, the South African Communist Party (SACP) and COSATU. Indeed, these relations are crucial to understanding the 1995 Labour Relations Act.

As negotiations for democracy unfolded in the 1990s, corporatism fast became an attractive option for the state, capital and labour (Kim and Van der Westhuizen, 2018). Indeed, despite the obvious political, social and economic differences between South Africa at the end of the 1980s and Western Europe in the 1970s both were confronted with the issue of how to contain workingclass militancy in the face of economic crisis (Bramble and Ollert, 2007). The foundations for South Africa's future corporatist framework were laid with the Laboria Minute of 1990, an agreement which stated that any future amendments of the LRA would be done in consultation with COSATU and other relevant parties. Habib (1997) identifies this as the moment at which the trade union began to be drawn into corporatist processes. However, this was not without extensive debate within the labour movement itself. There were those who argued that corporatist relations would weaken and co-opt the movement (Callincos, 1992; Desai and Habib, 1994), while others argued that it could create "strategic unionism" in support of "radical reforms" (Von Holdt, 1992: 33).

The redrafting of the LRA provided the first opportunity to use COSATU's position within the corporatist framework to push for radical reform. The LRA now had to provide a legislative framework in which the constitutional rights to fair labour practice, to form and join trade unions, to bargain collectively and to strike could be enacted. The fact that none of these rights had been guaranteed before, especially for black workers, was of course a significant step forward. However, the LRA also sought to develop an explicitly neo-liberal concern for "regulated flexibility" (Du Toit et al., 2003). As the Explanatory Memorandum that accompanied the Bill explained, the purpose of the new LRA was in line with the goals of the Reconstruction and Development Programme (RDP) and "seeks to balance the demands of international competitiveness and the protection of fundamental rights of workers... the draft Bill seeks to avoid the imposition of rigidities in the labour market" (Ministerial Task Team, 1995: 285-286). To achieve this the new LRA established new procedures for protected strike action, provided a voluntary framework for collective bargaining and established the Commission for Conciliation, Mediation and Arbitration (CCMA) to handle dispute resolution (Du Toit et al., 2003). However, the final LRA fell short of COSATU's demands.

COSATU demanded the legal duty to bargain, which had been possible under the 1956 LRA, 
that replacement labour during strikes be banned and the right to strike over dismissals and retrenchments, which the 1995 LRA restricted (Schroeder, 2002). Rejecting key provisions in the new LRA, COSATU took to the streets, with an estimated 70000 workers marching in June 1995. In a clever performance of Alliance politics, President Nelson Mandela joined the march but none of COSATU's demands were won (The Citizen, 1995: 4). As Schroeder (2002) highlights, the 1995 LRA contained necessary compromises to dismantle the apartheid labour regime. However, rather than present the legislation as a product of these necessary compromises COSATU (1995: n.p.) celebrated the new LRA as a "quantum leap for workers ... [and] a victory for workers" and refrained from continuing to campaign on any of these key demands.

A further problem with the 1995 LRA, which was little discussed at the time, was that it entrenched an insidious loophole regarding the employment relations of temporary employment services (TES) workers. Writing in 1999, Adler and Webster celebrated that the new LRA had, for the first time, brought all workers under one industrial relations system, but this was not entirely accurate. Curiously, the drafters of the LRA chose to define the employment relationship of workers employed by temporary employment services, more commonly known in South Africa as labour broker workers, in line with amendments introduced in the 1983 LRA, which stated that workers were "deemed" to be employees of their employer (the TES) and not the client (the company that hires the labour broker to provide workers). As Theron (2005) highlights, the only change that the drafters of the 1995 LRA made was to remove the word "deemed", thus continuing a legal mechanism instituted by the apartheid regime in order to control African migrant labour on fixed and temporary contracts. The consequences of this are well documented (Theron, 2005; Dickinson, 2017a, 2017b). Labour broker workers were effectively not afforded the right to strike or protection against unfair dismissal, as the client is not considered to be the employer. ${ }^{2}$ As Theron (2005) documents, after 1995 the number of workers employed through TES increased dramatically, and this has played a significant role in the restructuring of the working class.

\section{A "Crisis of Representation"}

The global restructuring of work has played a significant role in re-shaping working-class life and the composition of trade union membership in South Africa, as it has elsewhere in the world. The latest COSATU survey demonstrates that 90 per cent of its membership is comprised of permanent workers, with two-thirds of those members engaged in skilled or supervisory work (Bischoff and Tame, 2017: 66). The traditional blue-collar worker that was historically the base of COSATU has declined in significance, and very few atypical workers are organised in COSATU leading to what Webster (2006) describes as a "crisis of representation". However, COSATU's role within this crisis is seldom analysed.

COSATU recognised as early as 1997 the need to organise atypical workers. The September Commission (1997) outlined the particular kinds of workers that COSATU should look to organise: vulnerable sectors (defined as construction, farming, parts of retail, and catering and domestic work); vulnerable layers in organised sectors (specifically sub-contracted, outsourced, casualised, contract and part-time workers); the informal sector; immigrant workers; women workers; and skilled and white-collar workers. Reflecting on the challenges raised by flexible labour and the informal sector, COSATU outlined two scenarios: "continue with no change" or "commit resources to organising vulnerable layers" (September Commission, 1997). In the first scenario,

${ }^{2}$ This has subsequently changed due to amendments made to section 198 in 2014 (Runciman and Webster, 2017). 
COSATU predicted:

COSATU affiliates would fail to organise or defend the growing layers of 'flexible' workers. As subcontracting, casualising, labour-brokering become more common, they will undermine the unions' bargaining position, weakening the unions and undermining labour standards. COSATU would find it medals [sic] [struggles] to contest the labour market trends towards 'flexibility'. Ultimately, COSATU could end up being based in a shrinking section of the working class, as has happened to trade unions in a number of other countries (September Commission, 1997: n.p.).

However, when it comes to the recommendations made by the September Commission the focus on the "vulnerable layers" gets subsumed under a focus of organising skilled and white-collar workers. Indeed, in Chapter 7 of the September Commission, which focuses on organising new sectors, fifty-eight references are made to white-collar work or workers, compared to eleven mentions of non-standard work/employment and five mentions of vulnerable layers.

Furthermore, the recommendations that are made are disconnected from the realities faced by sub-contacted, outsourced and casualised workers. Many proposals remain at an abstract level - for example, "each affiliate needs to develop focussed campaigns to organise and defend these workers" (September Commission, 1997: n.p.). Others recommendations reveal the distance that already existed between precarious workers and COSATU. For instance, they recommend that the interests of vulnerable workers be included in collective bargaining (September Commission, 1997: n.p.) without being alive to the challenges of this or how it might be in conflict with the interests of the skilled and white-collar workers they also seek to organise. Nevertheless, the document does recognise that union officials and shop stewards do not take the problems of non-standard workers seriously. Some proposals that may have helped - such as developing flexible policies on union subs including lower rates, allowing periods of unpaid membership and demanding that employers pay union subscriptions - were never implemented.

It took over a decade for COSATU to begin to take up any campaigning around labour broking, calling for a ban in 2006. However, as Theron argues,

...the call to ban labour broking was made at least ten years too late. It was also a naïve demand. It focused attention on only one way in which employment has been externalised. It was also not a demand labour could win, given the global context ... [and] coupled with the fact that South Africa is a constitutional state. Even if it had been possible to implement a ban, labour brokers would in all likelihood have been able to reinvent themselves as 'services', as some have already done, and carry out the same activity under another guise (Theron, 2014: 9).

While the demand may have been naïve, COSATU was able to use its political relationship to the ANC to press for changes in the legislation. Shortly after President Zuma came to power, thanks in part to COSATU's backing (Ceruti, 2008), public hearings on labour broking were held that would eventually lead to significant new rights for labour broker workers (Runciman and Webster, 2017.

While COSATU may have been pivotal in initiating the process it was, however, not an active participant within it. COSATU leaders in the National Economic Development and Labour Council (NEDLAC) refused to take part in discussions, leaving it up to the state and capital as to how to amend the legislation. Furthermore, since the legislation came into effect, trade unions have not taken up any significant campaigning around the new rights; analysis I have made of the CCMA caseload demonstrates that a significant proportion of cases have been brought by advice offices, particularly the Casual Workers Advice Office (CWAO). 
The "crisis of representation" that confronts COSATU and other trade unions in South Africa cannot simply be attributed to neo-liberal restructuring without union involvement. As I have argued here, COSATU followed a particular strategy to organise the middle-class workers that now dominate its membership. While it utilised its institutional power, mediated through its political relationship to the ANC, to initiate a process of reform around the rights of TES workers it has largely been absent from shaping the content of these rights or their implementation. This, in turn, has weakened COSATU's associational power as it represents a shrinking section of the working class. This has not only created a crisis of representation but also a crisis of legitimacy for COSATU.

\section{A Crisis of Legitimacy: The Context of the 2019 LRA Amendments}

Arguably, the 2019 LRA amendments cannot be understood outside the context of the events at Marikana in 2012. Marikana encapsulated the crisis of legitimacy faced by the trade union movement both in the eyes of workers and of capital. The strikes across the platinum belt in 2012 were significant for the way in which they were organised through independent worker committees. Not only were the strikes independent of unions, in most instances they included members of multiple unions. Feeling that well-established unions - the COSATU-affiliated National Union of Mineworkers (NUM) in particular - were not carrying forward their demands, workers took it upon themselves to demand higher wages from their employers. As Buhlungu (2016: 145) argues, by breaking away from the NUM workers were "breaking away from the political monopoly" between COSATU, the ANC and capital. They were met with heavy state repression, resulting in the massacre of thirty-four striking mineworkers on 16 August 2012 (Sinwell and Mbatha, 2016).

The strike wave that followed the Marikana massacre - including work stoppages in the car industry, at various power stations and by City Power workers in Johannesburg, a truckers' strike and a farmworkers' strike - demonstrated that workers would no longer be restrained by their trade unions and that non-unionised workers such as farmworkers were beginning to organise more and more (Paret and Runciman, 2016). COSATU's failure to keep the working class quiescent necessitated a response from the state and capital, which was to facilitate further neo-liberal labour reforms.

\section{The Justification for Amending the LRA}

The impact assessment that accompanies the 2017 LRA Amendment Bill argues that strikes have been increasingly prevalent, prolonged and violent. This is a view that has entered common-sense knowledge about strikes and has even influenced how scholars have written about contemporary strike action in South Africa (Cheadle et al., 2017; Webster, 2017). However, these arguments are often based on a poor and selective interpretation of the available data. In fact, the data suggests that there is nothing particularly remarkable about strike trends in South Africa.

The Department of Labour motivates that strike action is increasing because the number of work stoppages is increasing, which is indeed the case (see Figure 1). But this is an imprecise measure of industrial action because of the vastly different lengths of time a work stoppage can take. Usually, it is the number of working days lost that is used as a barometer of industrial action. Figure 2 presents the number of working days lost between 2006 and 2017. While there are peaks in 2007, 2010 and 2014, reflecting the 2007 and 2010 public sector strikes and the 2014 platinum strike, overall the trend in the number of working days lost over the last decade is declining. Furthermore, as Bhorat and Tseng (2014) demonstrate, South Africa's depth of strike activity (the 
number of working days lost per strikers' working days per annum) and strikers' intensity (the number of strikers per 1000 employed workers) is comparable or, indeed, lower than middleincome and even high-income countries. The evidence therefore suggests that South Africa's levels of strike activity cannot be said to be rapidly increasing or significantly different from international trends.

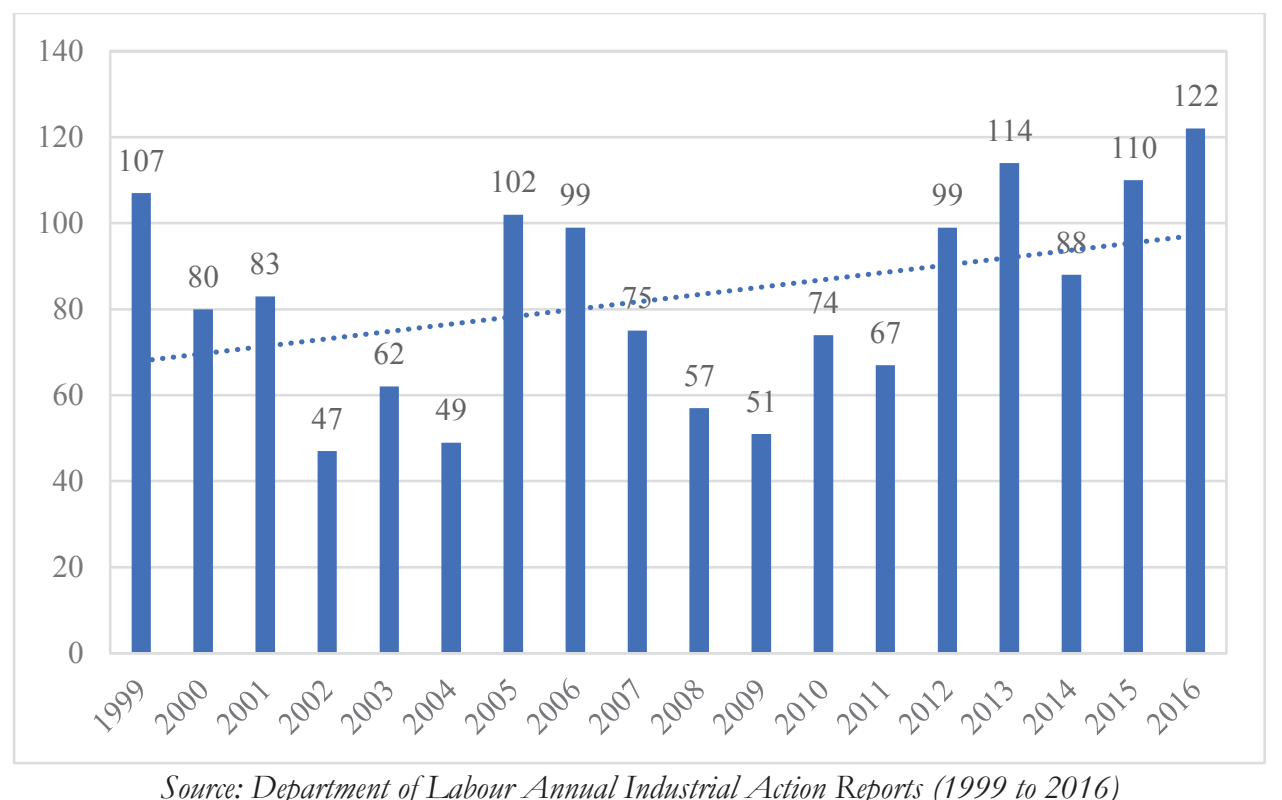

Figure 1. Number of industrial actions in South Africa, 1999-2016

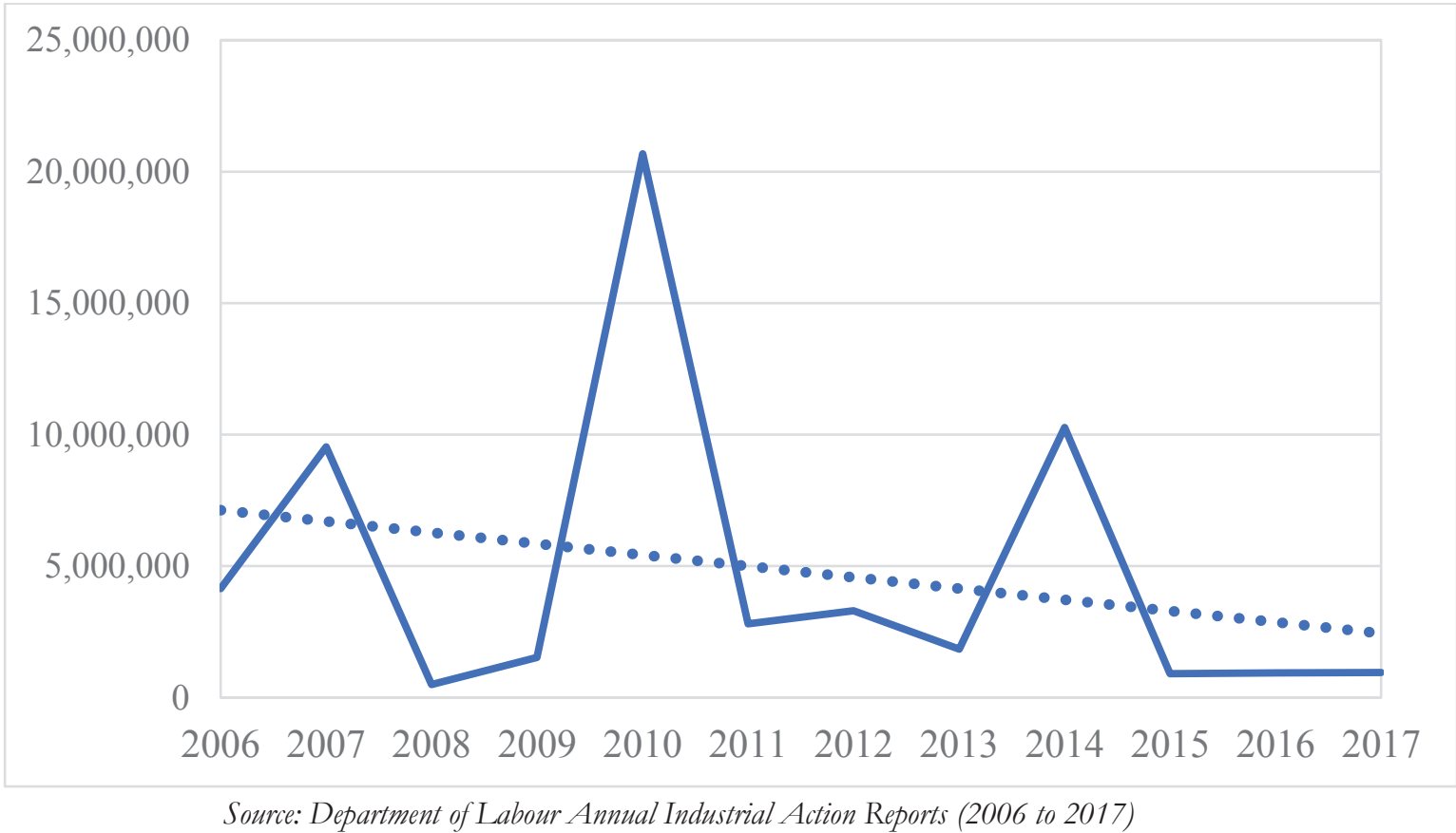

Figure 2. Number of working days lost due to industrial action, $2007-2017$ 
Another concern of the amendments has been to address strike violence. It is certainly the case that South Africa has witnessed violent strikes. However, there has been little attempt to actually quantify the levels of strike violence. Analysts have tended to focus on individual cases such as the 2006 private security sector strike (Webster, 2017), the 2007 public sector strike (Von Holdt, 2013) or the 2012 strikes in the platinum sector (Chinguno, 2015). The impact assessment that accompanies the Bill uses a report by the South African Institute for Race Relations on deaths during strikes to substantiate the argument that strike violence is increasing. While I do not want to diminish the significance of any violence during a strike, it is problematic to use such extreme cases to generalise to all strike action, especially when there is robust quantitative evidence on the number of instances of violence during labour protests.

Working with data from the South African Police Service's (SAPS) Incident Registration Information System (IRIS), I have been part of a team of researchers at the Centre for Social Change, University of Johannesburg, which has demonstrated that the vast majority of labour protests between 1997 and 2013, 88 per cent, were orderly in nature. Although from 2010 onwards there is a small increase in the number of disorderly incidents (see Figure 3), it can still be said that the vast majority of South Africa's labour protests are orderly in nature. While we do not have access to more recent data, there is no reason to think these trends will have altered dramatically.

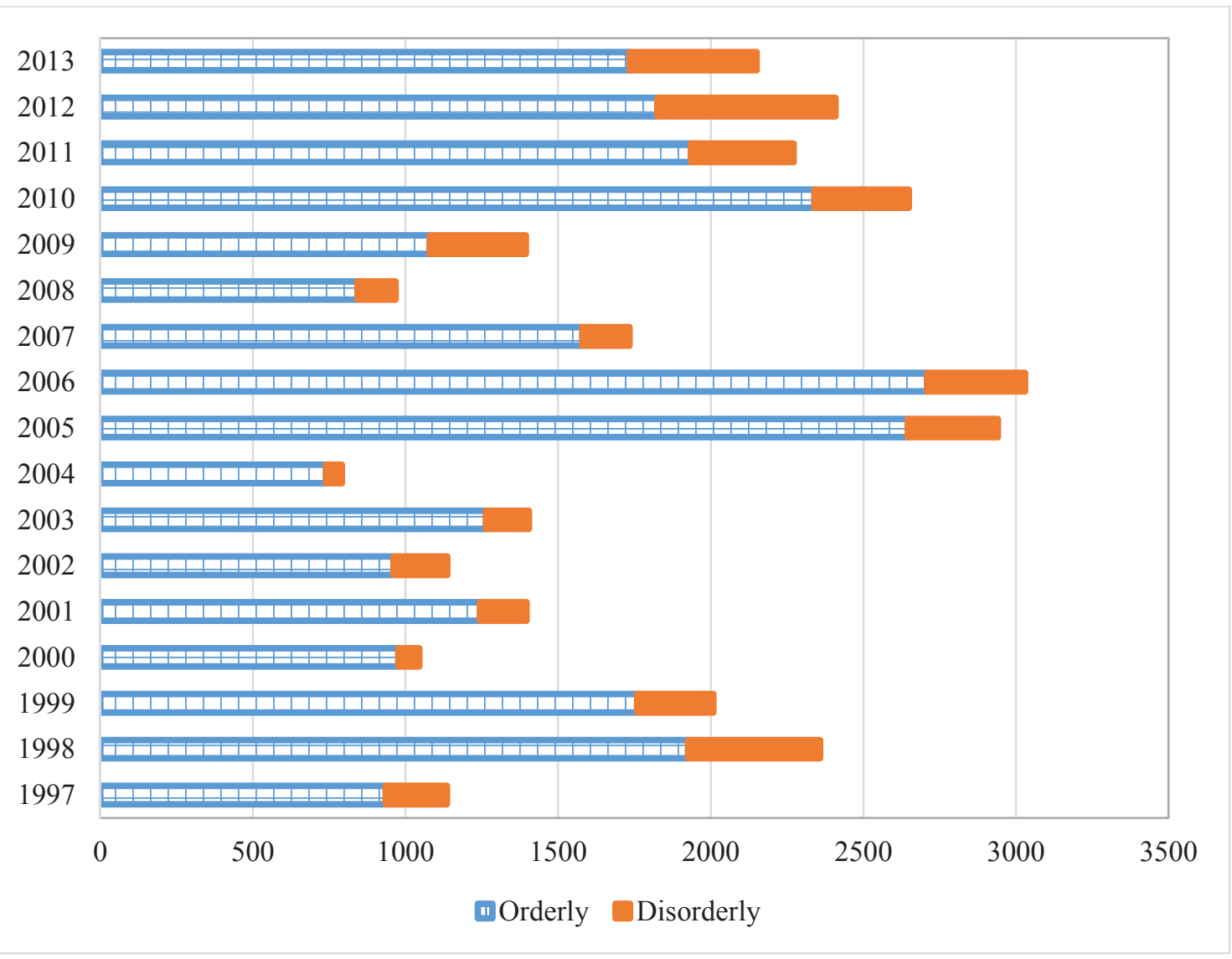

Source: Runciman et al. (2016)

Figure 3. Estimated number of orderly and disorderly labour protests, 1997-2013 
The analysis above underlines that the rationale for the LRA amendments was not made on the basis of robust evidence but rather the marshalling of facts that helped to support a particular ideological argument about the nature of contemporary strike action in South Africa. Indeed, I argue that the true intentions of the 2019 LRA amendments are not aimed simply at reducing violent strike action but at reducing the incidence of strikes in general.

\section{Restricting the Right to Strike: The Impact of the 2019 LRA Amendments}

In order to substantiate the argument that the 2019 LRA amendments are designed to restrict all strike action, it is necessary to outline what the changes to the LRA will mean. Table 1 provides a summary of the amendments that relate to strike action. This section explains the potential consequences of these amendments and why they are likely to restrict the ability of trade union members to embark on procedural strike action.

Table 1. Summary of 2019 LRA amendments

\begin{tabular}{|c|l|}
\hline Section of the LRA & Proposed amendment \\
\hline 69 & $\begin{array}{l}\text { Picketing rules have to be agreed before a certificate of non-resolution } \\
\text { of a mutual interest dispute is issued }\end{array}$ \\
\hline 95 & $\begin{array}{l}\text { Compulsory for registered trade unions to include provisions within its } \\
\text { constitution before embarking on strike action }\end{array}$ \\
\hline 135 & Extension of conciliation from 30 to 35 days \\
\hline 150 & Changes to advisory arbitration \\
\hline
\end{tabular}

When a trade union intends to take strike action, it refers a dispute of mutual interest to the CCMA or to the relevant bargaining council. A commissioner then attempts to mediate between the employers and the trade union to resolve the dispute at conciliation. If the commissioner is unable to resolve the dispute at conciliation a certificate of non-resolution is issued, commonly referred to as a strike certificate. After it has been issued the trade union must give the employer forty-eight hours' notice of any strike action. The conciliation process has now been extended to thirty-five days. While this may seem a relatively minor change, the impact of this amendment is that it gives the employers more time to prepare for strike action through stockpiling and the employment of alternative labour. This is further exacerbated by the introduction of compulsory picketing rules.

Previously, it was not a legal requirement that picketing rules be agreed before the certificate of non-resolution was issued. Now they have to be agreed prior to the certificate being issued. If the parties are unable to agree the picketing rules then the commissioner will have the power to determine what they are. The default picketing rules further reveal the extent to which the right to strike is under attack. While the default rules are intended to be used when workers, unions and employers are unable to mutually agree, the concern is that these regulations will become the norm and impose severe limitations on all strikes.

The default picketing rules require a statement of when and where a picket will take place. In addition, pickets will be limited to a maximum number of workers. Members of the public will be banned from showing solidarity with striking workers as pickets will be limited to striking workers and union members only. The default rules also provide commissioners with far-ranging powers to decide what workers can and cannot do on a picket. For example, they will be able to decide 
what songs can be sung, whether placards can be held, whether workers can be addressed by a union official and whether workers can speak to members of the public about their strike. Commissioners will not be required to justify any limitations they place on the activities of striking workers. This may not only undermine the right to strike, but also the right to freedom of expression. If any of the picketing rules are broken the trade union will be required to suspend the picket until it has satisfied a commissioner that it can control the picket. This opens up trade unions to having to suspend their picket for the slightest reason and fundamentally undermines the collective power of a strike. The default picketing rules entirely favour employers, who will know even before a certificate of non-resolution is awarded when and where the strike will take place, as it must be stated in the picketing rules. This provides employers ample time to stockpile, hire alternative labour and undertake other action to undermine workers' collective power (Runciman, 2018a).

The amendments also introduce a further change by requiring registered trade unions to include in their constitutions secret ballot provisions prior to strike action. The possibility of secret strike ballots had actually been introduced in a tabled amendment to the LRA in 2012. At that time COSATU vehemently opposed this, arguing:

It should be noted that balloting requirements were a distinct feature of the apartheid legislative regime. Its absence in the current LRA was no oversight but rather an acknowledgement of the extensive abuse of technicalities by employers around balloting to prevent industrial action. Its reintroduction reflects a fundamental attack not only on the right to strike but also on collective bargaining (COSATU, 2012: 11).

However, in 2018 COSATU, FEDUSA and NACTU presented the introduction of secret strike ballots as a minor alteration to the strike balloting procedures that registered trade unions were already required to have within their constitutions. They argue,

Unions and employers' organisations have been required for the past 23 years to have the mandatory requirement to ballot their members when they want to strike. The sole change to the balloting provisions in this bill is to insert the word secret before ballot. The majority of unions, political parties and other organisations elect their leadership through secret ballots... This insertion is a simply [sic] clarification as to what a ballot constitutes. It is in line with common law, practise [sic] and the Constitution. Organised labour is comfortable that it has protected workers' hard-won constitutional rights to strike (COSATU, FEDUSA and NACTU, 2018: 20-21).

The position of the three federations is that making strike ballots secret is only a clarification of existing practice, but I think this is a disingenuous claim. Previously, unions were free to implement strike ballots in line with the direct and participatory forms of democracy that have been integral to the trade union movement in South Africa (Desai, 2016). By imposing a secret ballot these traditions will be overridden. As the CWAO (2018: 7) argues, the secret ballot "undermine[s] the essential collective decision making of a strike... It not only individualises an otherwise collective decision but more fundamentally it wrests from the control of workers their ability to choose their own democratic processes and procedures". The amendments to the LRA do not permit employers to interdict strikes on the basis of technicalities around the ballot. However, as the experience of the CWAO demonstrates, the Labour Court has been increasingly willing to grant interim strike interdicts to employers even when they fail to meet the minimum evidentiary requirements (Schroeder and Wesso, 2018).

Finally, even if workers and unions comply with all of the new procedures outlined above, 
employers still have one final way in which they can frustrate strike action. New procedures around advisory arbitration mean that strikes may be resolved through an advisory arbitration panel led by a senior commissioner of the CCMA. An advisory arbitration panel can be established if the Minister of Labour or the Director of the CCMA deem it to be in the "public interest" or if it is requested by any party to the dispute. The amendment sets out criteria for "public interest" that are so wide that almost any strike could be subjected to advisory arbitration. Furthermore, employers will have the right to request advisory arbitration, which will obviously be in their interests to do as soon as a certificate of non-resolution is issued and even before the strike has started. While the process of advisory arbitration does not suspend the strike, it draws union officials into highly technical procedures. Furthermore, the ruling by the arbitration panel is binding unless rejected by the trade union within seven days, after consulting with their members (Runciman, 2018b).

Viewing the amendments together, it is clear that the intention of the legislation is not to simply reduce violent strikes. Indeed, if that had been the case the amendments should have considered regulating the use of alternative labour during strikes, one of the most common causes of conflict. Instead these amendments are aimed at restricting procedural strikes in general. The impact of this may simply be to increase the number of unprocedural strikes (see Runciman, 2018c). If we are to understand why COSATU championed these amendments then we must analyse what they gained from them.

\section{Strengthening Trade Union Institutional Power through Legal Reform}

It is no accident that the LRA amendments were tabled at the same time as the National Minimum Wage (NMW) Bill. For both COSATU and the ANC the introduction of the NMW was an important attempt to restore the legitimacy of both organisations while drawing a strategic focus away from the LRA amendments. Indeed SAFTU, in its campaigning against the Bills, frequently focused on the NMW and neglected to focus on the LRA amendments (Dor, 2018).

A significant but overlooked aspect of the LRA amendments was that they protect the status of trade unions within bargaining councils. Declining trade union membership has impacted the ability of trade unions to act as representatives within bargaining councils. Previously, employer organisations had to employ the majority of employees and unions had to represent the majority of employees in order for collective agreements to be extended to non-union members. Now, the Minister of Labour can extend collective agreements to non-parties as long as the employer organisations employ the majority of employees even when a union does not organise the majority of the workers. This only serves to bolster the power of unions within sectors that have bargaining councils, and allows greater scope for new bargaining councils to be established.

It could be argued that amending the basis upon which representivity is calculated will strengthen collective bargaining and afford workers greater protections. However, analysis of bargaining council agreements by Bassier (2018) has highlighted that as many as 80 per cent of bargaining council agreements allow for downward variation from the Basic Conditions of Employment Act (BCEA) - that is the legislation that is intended to be the minimum floor of labour rights. Therefore, rather than extend worker rights bargaining council agreements have been undermining them.

Furthermore, rather than acting as an incentive to organise non-standard workers, COSATU has previously argued against their inclusion in how the number of employees is calculated for representivity (COSATU, 2012). While the wording of the amendment does not mean that the Registrar or the Minister must exclude non-standard employees there is every possibility that 
COSATU will lean on its political relationship to the ANC and state machinery to ensure that nonstandard employees are excluded. For the CWAO this amendment represents

...nothing more than a cynical move by trade unions to safeguard their waning influence. Instead of addressing their declining membership by organising new workers, the trade union federations are exchanging hard-won workers' rights, for which they have no mandate from the majority of workers, for the protection of Bargaining Councils (CWAO, 2018: 9).

An analysis of the 2019 LRA amendments raises serious concerns about the ends to which COSATU, once a key organisation in the liberation struggle, has used its institutional power.

\section{Conclusion}

The analysis presented in this article offers a challenge for the use of the PRA and the analysis of institutional power. By situating institutional power within an analysis of corporatism, I argue that institutional power develops further analytical utility, which is attentive to class forces. In addition to this, in the specificities of the South African context, corporatism also provides an avenue for understanding how the specific forms of institutional power that have been forged by COSATU are related to their political relationship to the ANC, thus providing a more comprehensive account of how institutional power has been shaped.

The article not only considers what gives rise to institutional power but also how it has been strategically used. Understanding this requires a wider consideration of COSATU's associational and structural power as well as its waning political influence. By analysing the 1995 LRA and the 2019 amendments this article is able to give some consideration as to how COSATU's institutional power has unfolded through time. Rather than viewing the 1995 LRA as an unqualified victory, as is commonly the case within the literature (Adler and Webster, 1999), this article highlights how significant compromises within the 1995 LRA entrenched neo-liberalism in South Africa, the unintended consequences of which have served to undermine the power of trade unions and the working class overall.

The analysis presented within this article demonstrates how neo-liberal restructuring in South Africa emerged hand-in-hand with corporatism. The 1995 LRA was the first and one of the most significant pieces of legislation to be enacted by the first democratic government. While it was undoubtedly a significant step forward for South African workers, particularly black South African workers, it also set out an explicitly neo-liberal path focused on "regulated flexibility" (Du Toit et al., 2003), an objective of both corporatism and neo-liberalism (Humphrys, 2018). While it could be argued that the compromises of the 1995 LRA were necessary in order to formally end the apartheid labour regime, this does not mean we should negate an understanding of COSATU's agency in resisting the forces of neo-liberalism.

As this article argues, COSATU made strategic choices about whom to organise, and in doing so chose to neglect some of the most vulnerable sections of the South African labour market. In the absence of organised labour, the number of precarious workers has grown considerably. While COSATU did utilise its institutional power to initiate reforms to the LRA to enhance protections for vulnerable workers, this has translated into little concrete organising of these workers. Indeed, if anything, the 2019 amendments illustrate that COSATU is willing to act against the interests of these workers in order to shore up its own structural, associational and institutional power.

Compared to the negotiations on the 1995 LRA, COSATU was in a much weaker position when it came to the negotiations on the amendments to the LRA that began in 2014. This may 
raise questions about the contemporary nature of corporatism, especially when there is a general consensus that NEDLAC has generally failed to be an effective institution (Kim and Van der Westhuizen, 2018). However, the 2019 LRA amendments provide a case in which corporatist structures were revived in the service of advancing neo-liberalism. Furthermore, it demonstrates how the incorporation of COSATU into a neo-liberal corporatist project saw it use its institutional power against the interests of the working class in the defence of capital. While South Africa's new strike laws may still be considered as more progressive than elsewhere in the world (Hepple, Le Roux and Sciarra, 2015), the amendments do represent a significant rolling back of the right to strike - a right that was fought for in the struggle against apartheid. In the context of South Africa, one of the most unequal countries in the world, the rolling back of the right to strike will have significant implications for the working class and for inequality.

The analysis presented in this article supports the critique of the PRA advanced by Nowak (2018) - that as serious labour scholars we cannot analyse power resources without seriously considering to what ends those resources are used, especially if they are used against the interests of the working class. In the South African case, serious questions have to be asked about the current prospects for trade union revitalisation and the challenges this poses for the labour movement as a whole.

\section{REFERENCES}

Adler, G. and E. Webster. (1999) Challenging Transition Theory: The Labour Movement, Radical Reform and Transition to Democracy in South Africa. Politics and Society, 23(3): 75-106.

Baccaro, L. (2003) What is Alive and What is Dead in the Theory of Corporatism? British Journal of Industrial Relations, 41(4): 683-706.

Bassier, I. (2018) Summary Review of Bargaining Council Agreement. Unpublished research paper for Casual Workers Advice Office, Johannesburg. Received by author 9 August 2018.

Beresford, A. (2016) South Africa's Political Crisis: Unfinished Liberation and Fractured Class Struggle. London: Palgrave Macmillan.

Bhorat, H. and D. Tseng. (2014) South Africa's Strike Data Revisited. https://www.brookings.edu/blog/africain-focus/2014/04/02/south-africas-strike-data-revisited (accessed 7 February 2019).

Bischoff, C. and B. Tame. (2017) Labour Aristocracy or Marginal Labour Elite? In Labour beyond Cosatu: Mapping the Rupture in South Africa's Labour Landscape, edited by A. Bezuidenhout and M. Tshoaedi. Johannesburg: Wits University Press.

Bramble, T. and N. Ollert. (2007) Corporatism as a Process of Working-class Containment and Roll-back: The Recent Experiences of South Africa and South Korea. Journal of Industrial Relations, 49(4): 569-589.

Buhlungu, S. (2016) The Paradox of Trade Union Action in Post-Apartheid South Africa. In Domains of Freedom: Justice, Citizenship and Social Change in South Africa, edited by T. Keep, M. Levin and B. von Lieres. Cape Town: UCT Press.

Callinicos, A. (1992) Social Democratic Dreams or Class Struggle Realism. South African Labour Bulletin, 16(6).

Casual Workers Advice Office (CWAO) (2018) Submission to the Parliamentary Portfolio Committee on Labour on the Labour Relations Amendments Bill, the National Minimum Wage Bill and the Basic Conditions of Employment Bill.

http://www.cwao.org.za/downloads/news/CWAO\%20submission $\% 20$ to $\% 20$ parliament $\% 2010.01 .2$ 018\%20final.pdf (accessed 8 April 2018).

Ceruti, C. (2008) African National Congress Change in Leadership: What Really Won It for Zuma? Review of African Political Economy, 35(115): 107-114. 
Cheadle, H., B. Conradie, T. Cohen, D. du Toit, E. Fergus, M. Jacobs and A. Steenkamp. (2017) Strikes and the Law. Durban: Lexis Nexis.

Chinguno, C. (2013) Marikana: Fragmentation, Precariousness, Strike Violence and Solidarity. Review of African Political Economy, 40(138): 639-646.

Congress of South African Trade Unions (COSATU) (1995) A New LRA - A Workers' Victory. Shopsteward. http://www.cosatu.org.za/show.php?ID=2085\#ART15 (accessed 16 May 2019).

Congress of South African Trade Unions (COSATU) (2012) COSATU Submission on the Labour Relations Amendment Bill [B16-2012] and the Basic Conditions of Employment Amendment Bill [B15-2012]. http://www.cosatu.org.za/show.php?ID=6379 (accessed 23 May 2018).

Congress of South African Trade Unions (COSATU), Federation of Unions of South Africa (FEDUSA) and National Council of Trade Unions (NACTU) (2018) Joint Submission on the National Minimum Wage, Basic Conditions of Employment Amendment and Labour Relations Amendment Bills. Received by author 22 March 2018.

Department of Labour (1999 to 2017) Annual Industrial Action Reports. Pretoria: Government Printer.

Desai, A. (2016) In the Name of Democracy? Daily Maverick, 28 September 2016. https://www.dailymaverick.co.za/opinionista/2016-09-28-in-the-name-of-democracy/\#.WsngzC5 ubuo (accessed 8 April 2018).

Desai, A. and A. Habib. (1997) Labour Relations in Transition: The Rise of Corporatism in South Africa's Automobile Industry. The Journal of Modern African Studies, 35(3): 495-518.

Dickinson, D. (2017a) Institutionalised Conflict, Subaltern Worker Rebellions and Insurgent Unionism: Casual Workers' Organisation and Power Resources in the South African Post Office. Review of African Political Economy, 44(153): 415-431.

Dickinson, D. (2017b) Contracting Out of the Constitution: Labour Brokers, Post Office Casual Workers and the Failure of South Africa's Industrial Relations Framework. Journal of Southern African Studies, 43(4): 789-803.

Dor, L. (2018) Final Nail in Coffin of Union Movement? https://karibu.org.za/final-nail-in-coffin-ofunion-movement (accessed 7 February 2019).

Du Toit, D., T. Cohen, B. Conradie, C. Cooper, G. Giles, S. Godfrey and A. Steenkamp. (2003) Labour Relations Law: A Comprehensive Guide. Cape Town: Juta.

Fine, B. (2016) Across Developmental State and Social Compacting: The Peculiar Case of South Africa. ISER Working Paper No. 2016/1. Colchester, UK: Institute for Social and Economic Research, University of Essex.

Gallas, A. (2016) “There is Power in a Union": A Strategic-relational Perspective on Power Resources: In Monetary Macroeconomics, Labour Markets and Development, edited by A Truger, E. Hein, M. Heine and F. Hoffer. Berlin: Metropolis.

Gallas, A. (2018) Class Power and Union Capacities: A Research Note on the Power Resources Approach. Global Labour Journal, 9(3): 348-352.

Habib, A. (1997) From Pluralism to Corporatism: South Africa's Labour Relations in Transition. Politikon, 24(1): 57-75.

Hepple, B., R. le Roux and S. Sciarra (2015) Laws Against Strikes: The South African Experience in an International and Comparative Perspective. Cape Town: Juta.

Humphrys, E. (2018) Simultaneously Deepening Corporatism and Advancing Neoliberalism: Australia Under the Accord. Journal of Sociology, 54(1): 49-63.

Humphrys, E. and D. Cahill. (2017) How Labour Made Neoliberalism. Critical Sociology, 43(4-5): 669-684.

Kim, Y. and J. van der Westhuizen (2018) Corporatism as a Crisis Response to Democratisation? Comparing the Rise of Corporatism in South Korea and South Africa. Politikon, 45(2): 291-308.

Ministerial Task Team (1995) Explanatory Memorandum to the Labour Relations Act (1995). Industrial Law Journal, 16: 278-336. 
Molina, O. and M. Rhodes (2002) Corporatism: The Past, Present and Future of a Concept. Annual Review of Political Science, 5: 305-331.

Nowak, J. (2018) The Spectre of Social Democracy: A Symptomatic Reading of the Power Resources Approach. Global Labour Journal, 9(3): 353-360.

Panitch, L. (1981) Trade Unions and the Capitalist State. New Left Review, 125: 21-43.

Paret. M. and C. Runciman (2016) The 2009+ South African Protest Wave. Working USA: The Journal of Labor and Society, 19: 301-319.

Parks, M. (2018) Parliament Gives New Labour Laws the Green Light. https://www.iol.co.za/businessreport/opinion/opinion-parliament-gives-new-labour-laws-the-green-light-15246902 $\quad$ (accessed 7 February 2019).

Runciman, C. (2018a) Why Changes to Picketing Rules Pose a Threat to Strikes. The Conversation Africa. https:/ / theconversation.com/why-changes-to-picketing-rules-in-south-africa-pose-a-threat-to-strikes104598 (accessed 18 March 2019).

Runciman, C. (2018b) South Africa's Strike Rate Isn't as Bad as It's Made Out to Be. The Conversation Africa. https://theconversation.com/south-africas-strike-rate-isnt-as-bad-as-its-made-out-to-be-95470 (accessed 18 March 2019).

Runciman, C. (2018c) New Amendments to Labour Legislation are Likely to Increase Unprotected Strikes. Business Day. https://www.businesslive.co.za/bd/opinion/2018-02-08-new-amendments-to-labourlegislation-are-likely-to-increase-unprotected-strikes (accessed 17 May 2019).

Runciman, C., P. Alexander, M. Rampedi, B. Moloto, B. Maruping, E. Khumalo and S. Sibanda (2016) Counting Police Recorded Protests: Estimates Based on SAPS Data. Johannesburg: South African Research Chair in Social Change, University of Johannesburg.

Runciman, C. and E. Webster. (2017) Worker Organisation and the Law: Then and Now. South African Labour Bulletin, 41(4): 21-23.

South African Federation of Trade Unions (SAFTU) (2018) Memorandum Handed Over on the 25 April General Strike. http://saftu.org.za/memorandum-handed-over-on-the-25-april-general-strike (accessed 7 February 2019).

Satgar, V. and R. Southall. (2015) COSATU in Crisis. Sandton: KMM Review Publishing.

Schmalz, S., C. Ludwig and E. Webster. (2018) The Power Resources Approach: Developments and Challenges. Global Labour Journal, 9(2): 113-134.

Schmalz, S., C. Ludwig and E. Webster. (2019) Power Resources and Global Capitalism. Global Labour Journal, 10(1): 84-90.

Schroeder, I. (2002) Proposed Amendments Slitting the Working Class's Throat: The Politics of the Proposed Labour Law Amendments. South African Labour Bulletin, 24: 5.

Schroeder, I. and R. Wesso (2018) Labour Court Judges Block Workers' Right to Strike. https://mg.co.za/article/2018-10-19-00-labour-court-judges-block-workers-right-to-strike (accessed 8 February 2019).

September Commission (1997) The Report of the September Commission on the Future of the Unions. http://www.cosatu.org.za/show.php?ID=2148 (accessed 8 April 2018).

Sinwell, L. and S. Mbatha. (2016) The Spirit of Marikana: The Rise of Insurgent Trade Unionism. London: Pluto Press.

The Citizen (1995) Mandela Pledges Support for 20000 JHB Protesters, 7 June 1995: 4.

Theron, J. (2005) Intermediary or Employer? Labour Brokers and the Triangular Employment Relationship. Industrial Law Journal, 26: 618-649.

Theron, J. (2014) Non-Standard Employment and Labour Legislation: The Outlines of a Strategy. http://www.idll.uct.ac.za/sites/default/files/image tool/images/3/01\%20of $\% 202014 \% 20-\% 20$ Nonstandard \%20employment $\% 20-02030 \% 20$ November $\% 202014$.pdf (accessed 7 February 2019). 
Von Holdt, K. (1987) The Political Significance of COSATU: A Response to Plaut. Transformation, 5: 94 103.

Von Holdt, K. (1992) What is the Future of Labour? South African Labour Bulletin, 16(8): 16-26.

Von Holdt, K. (2013) COSATU Members and Strike Violence: What We Learn from the Quantitative and Qualitative Data. In COS ATU's Contested Legacy: South African Trade Unions in the Second Decade of Democracy, edited by Sakhela Buhlungu and Malehoko Tshoaedi. Leiden: Brill.

Webster, E. (2006) Trade Unions and the Challenge of the Informalisation of Work. In Trade Unions and Democracy: COS ATU Workers' Political Attitudes in South Africa edited, by S. Buhlungu. Cape Town: HSRC Press.

Webster, E. (2017) Marikana and Beyond: New Dynamics in Strikes in South Africa. Global Labour Journal, 8(2): 139-158.

\section{BIOGRPAHICAL NOTE}

CARIN RUNCIMAN is an Associate Professor based at the Centre for Social Change, University of Johannesburg, and a member of the management committee for the Casual Workers Advice Office. Her research specialises in working-class politics and mobilisation in post-apartheid South Africa. [Email: crunciman@uj.ac.za] 